\title{
Impact Assessment of Precision Water Management on Nutrient Load from Paddy Field in Lake Inba-numa Watershed
}

\author{
Koshi Yoshida ${ }^{1 *}$, Issaku Azechi ${ }^{2}$, Toshiaki Iida ${ }^{3}$, Shigeya Maeda ${ }^{1}$ and Hisao Kuroda ${ }^{1}$ \\ ${ }^{1}$ College of Agriculture, Ibaraki University, Japan
}

${ }^{2}$ National Agriculture and Food Research Organization, Japan

${ }^{3}$ Graduate School of Agricultural and Life Sciences, The University of Tokyo, Japan

*Corresponding author: Koshi Yoshida, College of Agriculture, Ibaraki University, Japan

\begin{abstract}
In this study, the impact of nutrient load reduction by precision water management was evaluated to improve the water environment of Lake Inbanuma. Kashima district, which was managed by Inbanuma land improvement district, was selected for the test site. Paddy water level, nitrogen and phosphorus concentration were monitored at lino pumping station and paddy drainage during 2012-2014. From the monitoring data, water balance and nutrients balance were estimated. As a result, average nitrogen load from paddy was $36 \mathrm{kgN} / \mathrm{ha} /$ season and phosphorus load were $7 \mathrm{kgP} / \mathrm{ha} / \mathrm{season}$. Precision water management by automatic irrigator can reduce $65 \%$ of irrigation water, $58 \%$ of nitrogen load and $43 \%$ of phosphorus load. Finally, installation cost of automatic irrigator in Kashima district was estimated and compare to construction cost of waste water treatment plant.
\end{abstract}

Keywords: Water environmental conservation; Automatic irrigator; Cost-benefit

\section{Introduction}

Irrigation water is essential for food production especially in paddy rice, and much water was withdrawn from water sources compare to other water use sector [1]. In Japan, water delivery system for agriculture was highly-developed and managed by land improvement district [2]. The 1st priority of irrigation is water supply to avoid the water stress, however, saving a labor input for agricultural land management such as weed control also the important factor. Therefore, farmers want to input much water for their paddy to save a labor cost [3]. However, much irrigation water leads much energy consumption for pumping, as a result, water fee also increases. In addition, increase of drainage water cause a much nutrient effluent to downstream water environment $[4,5]$. Historically, water delivery system in paddy agriculture has been supply-oriented system. However recent innovation of field monitoring or automatic regulation system will change it to demand-oriented system. In this study, the impact of precision water management by automatic irrigator was evaluated to improve the water management system in paddy without the additional labor input.

\section{Study Area}

For the test site, Kashima district was selected which was managed by Inbanuma land improvement district and having 46.1 ha benefit area (Figure 1). Figure 2 shows the monitoring paddy fields having 6.48 ha. All of these paddy fields were cultivated by same farmer group. Irrigation water was pumped up from Inbanuma lake, and water from paddy was drained to Inbanuma again flowing through Kashima river. In this paddy fields, open type drainage canal was not existed, and subsurface drainage system was installed in all paddies so that all drained water, which was percolated through paddy soil layer and overflowed from paddy outlet, gathers to drain pipe. Inbanuma lake is closed water area and eutrophic [6,7]. Therefore, drainage water from paddy fields was one of the pollution sources. Although drainage water from paddy have relatively low nutrient concentration compare to that from upland, drainage water amount is larger. Therefore, nutrient load from paddy fields could not be negligible for the conservation of lake water environment. 


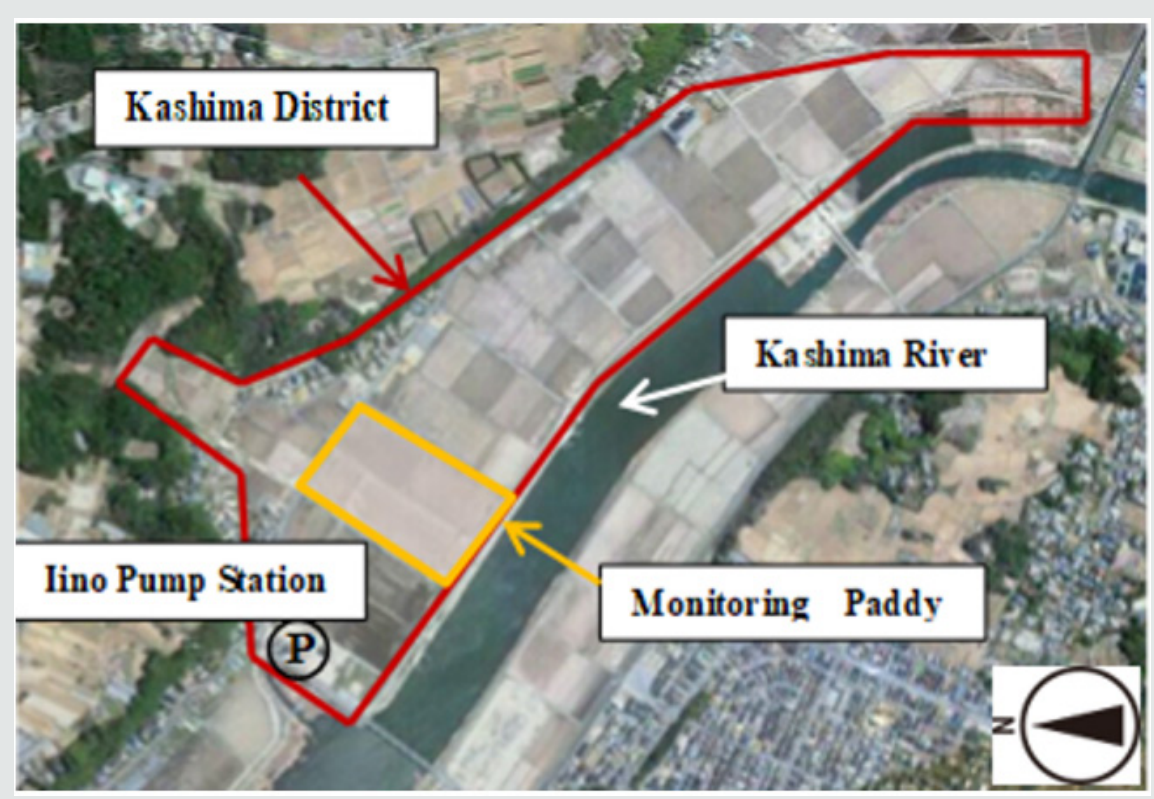

Figure 1: Outline of Kashima district.

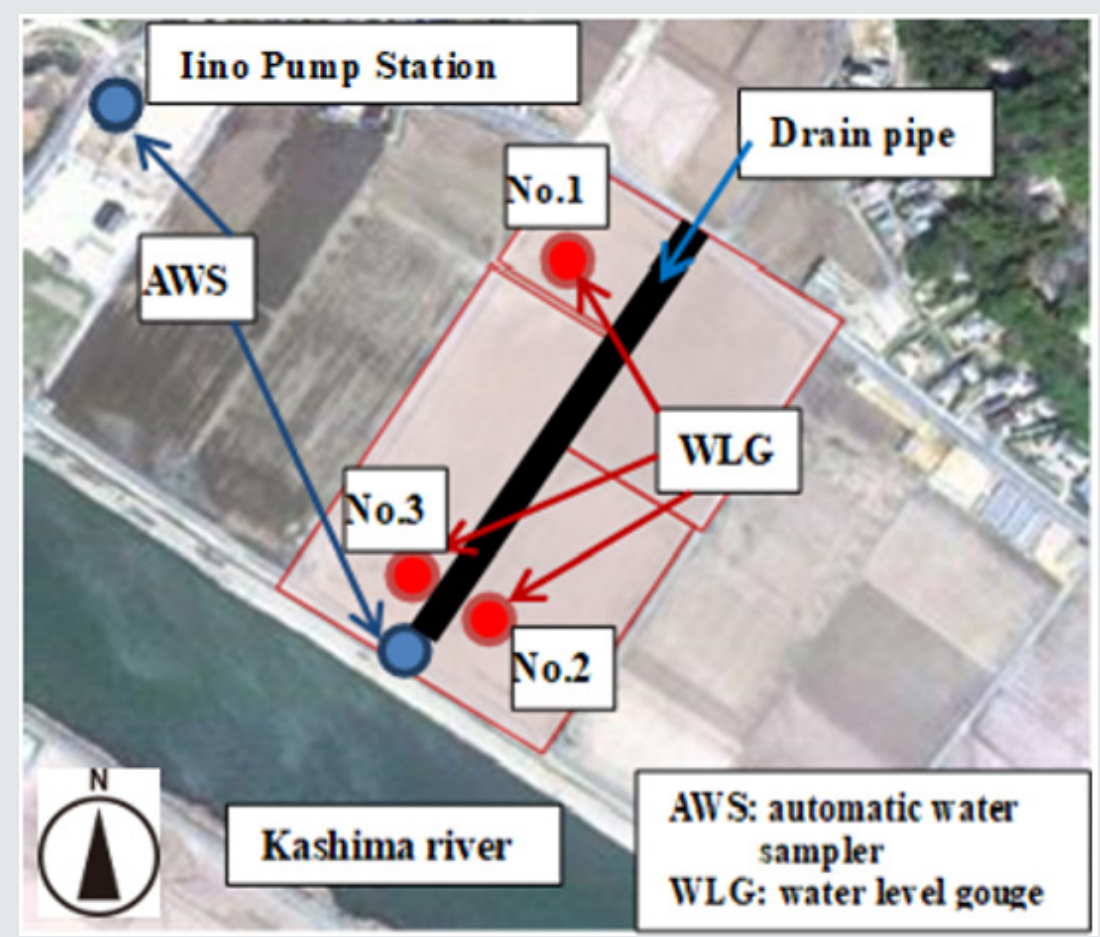

Figure 2: Monitoring paddy fields.

\section{Field Measurement}

To evaluate the water balance such as how much water was irrigated, evaporated and drained, paddy water level was monitored in hourly basis at 3 paddies by using HOBO U20 water level loggers (Onset Co. Ltd.). Water quality at Iino pumping station and paddy drainage pipe was measured in daily basis (at noon) such as soil sediment (SS), total nitrogen (TN), nitrate nitrogen $\left(\mathrm{NO}_{3}-\mathrm{N}\right)$, ammonium nitrogen $\left(\mathrm{NH}_{4}-\mathrm{N}\right)$, chemical oxygen demand (COD) and total phosphorous (TP). Meteorological data also measured at lino pumping station for calculating evapotranspiration. Measured items were rainfall, solar radiation, wind speed, air temperature, relative humidity and atmospheric pressure. Rice variety was Momiroman which was not for human food but for livestock feeding. Observation period was from 4/Jun/2012 to 22/Sep/2014 for 3 years, but only irrigation periods. A questionnaire to the farmer also conducted to grasp the fertilizer input or land management practices. Figure 3 shows the variation of rainfall, paddy water depth, TN and TP concentration of in and outflow at paddy field during observation period. In 2012, paddy water depth was controlled relatively deep, so the amount of drained water also became larger than 2013-2014. Much drained water leads much TN and TP concentration in 2012. 


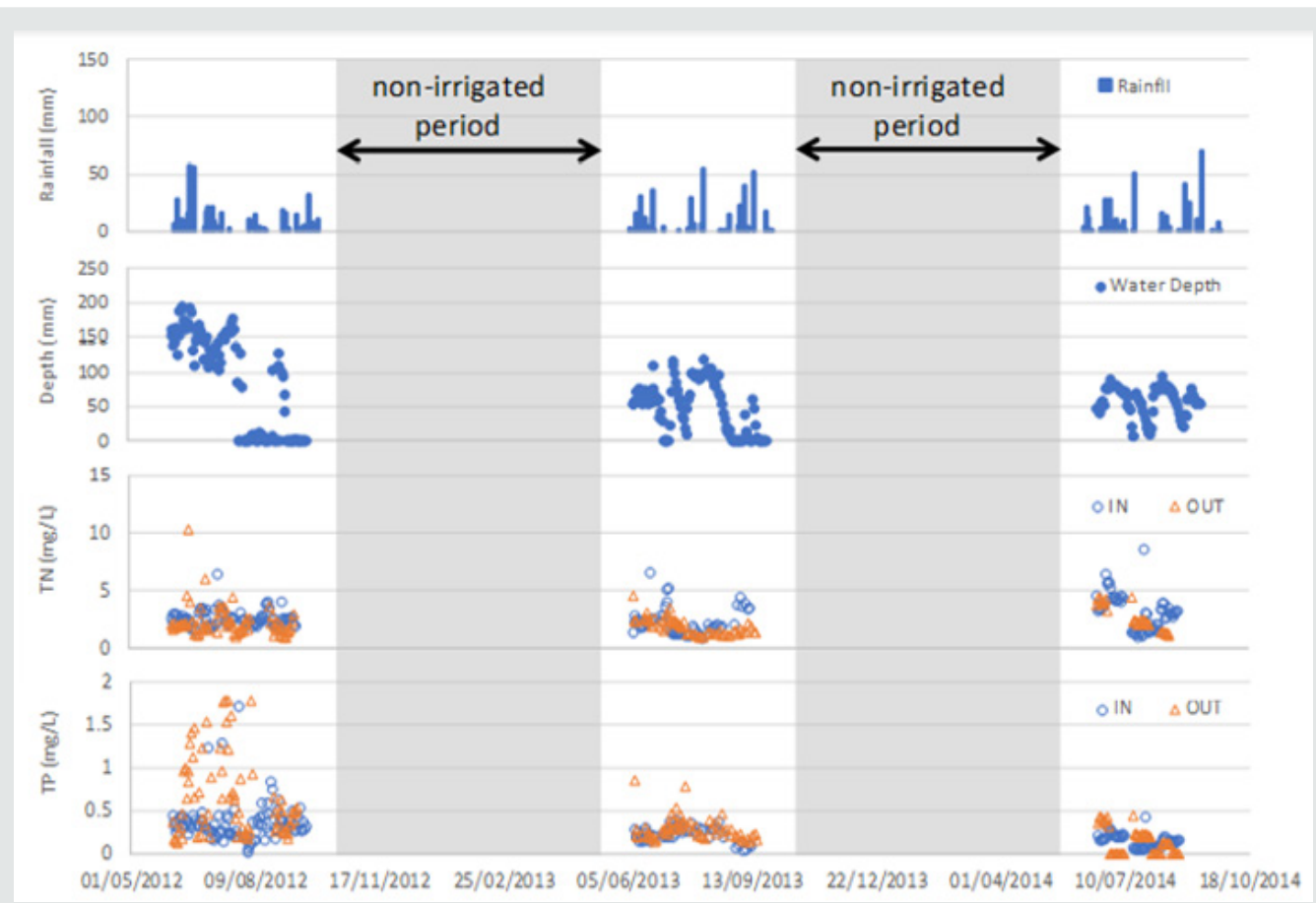

Figure 3: Variation of rainfall, water depth, TN and TP concentration of observed paddy during irrigated period (2012-2014).

\section{Result and Discussion}

The pollution load through surface runoff can be reduced by controlling the surface drainage water volume $[8,9]$. Such water management leads water and irrigation cost saving, and pollution load to downstream water environment also can be reduced. For saving water and farmer's labor input, automatic irrigation system was developed and introduced in some irrigation district, Japan. Figure 4 shows schematized description of float auto irrigator. Farmers just set the target water level and auto irrigator supply water until float level increase at target depth. In this study, the effect of this auto irrigation system on water saving and nutrient load reduction was estimated and compared with conventional water management case. From observed data, water balance was estimated during 2012-2014. Table 1 shows annual averaged water balance in irrigation period during 2012-2014. At the monitoring paddy fields, $2045 \mathrm{~mm} /$ year water was pumped up for irrigation and $53 \%$ of supplied water was released by surface drainage from paddy outlet in current situation. Therefore, there was still large possibility to save water by introducing elaborated water management system to reduce surface drainage water [8]. With installing auto irrigator case, the water saving effect was about $1335 \mathrm{~mm}(65 \%)$ and energy consumption for pumping also can be saved. As a result, farmer can save water fee which farmer pay to land improvement district for the maintenance and operation of water delivery facilities.

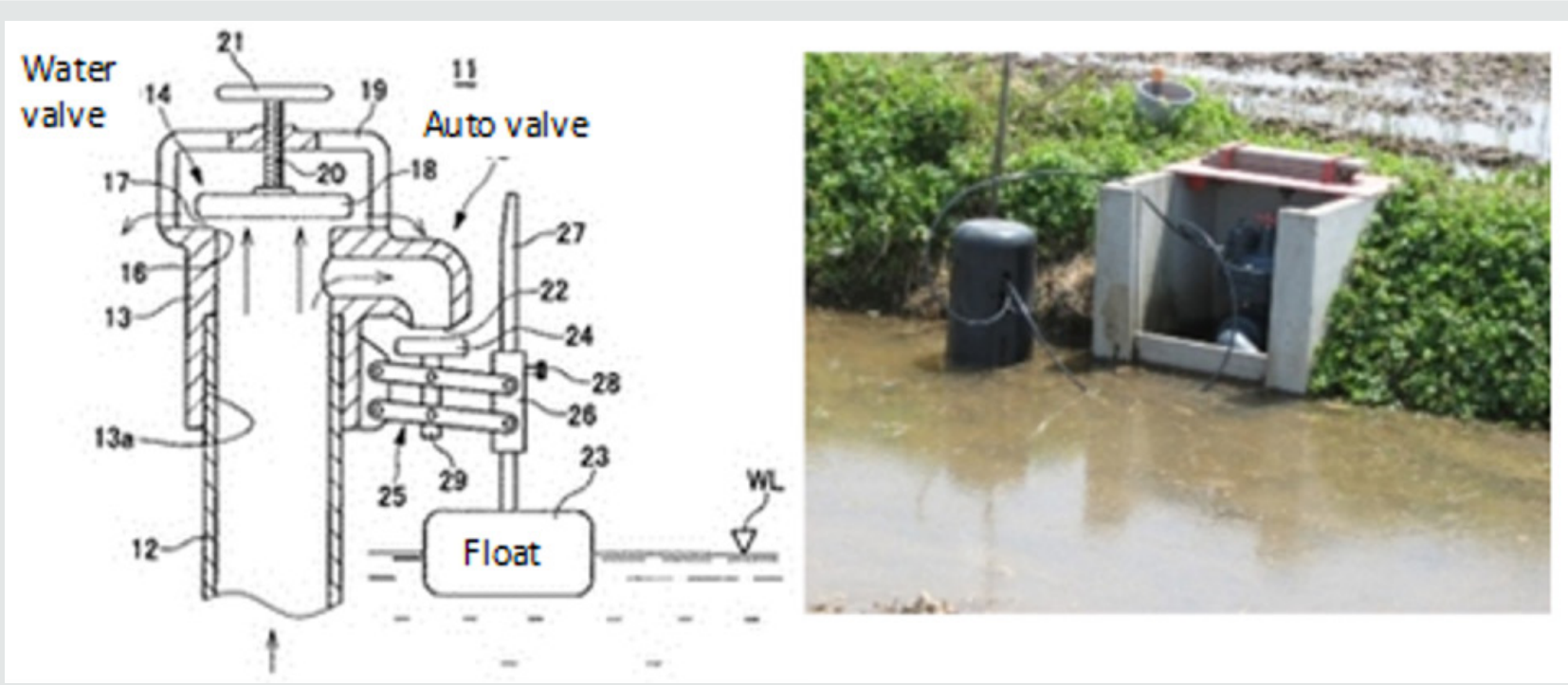

Figure 4: schematized description of float auto irrigator. 
Table 1: Annual averaged water balance in irrigation period during 2012-2014.

\begin{tabular}{|c|c|c|c|c|c|}
\hline & & \multicolumn{2}{|c|}{ Conventional } & \multicolumn{2}{|c|}{ with Auto Irrigator } \\
\hline & & $(\mathrm{mm})$ & (\%) & $(\mathrm{mm})$ & (\%) \\
\hline \multirow{3}{*}{ INPUT } & rainfall & 931 & 31 & 931 & 57 \\
\hline & irrigation & 2045 & 69 & 710 & 43 \\
\hline & Total & 2976 & 100 & 1641 & 100 \\
\hline \multirow{4}{*}{ OUTPUT } & evapotrans & 528 & 18 & 528 & 32 \\
\hline & surface drainage & 1569 & 53 & 0 & 0 \\
\hline & percolation & 879 & 30 & 1113 & 68 \\
\hline & Total & 2976 & 100 & 1641 & 100 \\
\hline
\end{tabular}

Table 2 shows annual averaged nitrogen and phosphorus balance in irrigation period during 2012-2014. Estimated nitrogen and phosphorus load from paddy by surface and percolation flow were $36 \mathrm{kgN} / \mathrm{ha}$ and $7 \mathrm{kgP} / \mathrm{ha}$. Estimated nutrients load was relatively larger compare to literature value $23.3 \mathrm{kgN} /$ ha and 3.75 $\mathrm{kgP} / \mathrm{ha}$ which were observed average value in Japan [9]. Generally, in the conventional paddy field, $90-120 \mathrm{~kg} / \mathrm{ha}$ nitrogen was recommended in food rice cultivation. However, much nitrogen was fertilized in this monitoring paddy compared with conventional one. Because, in feed rice cultivation, farmers do not need to pay attention to a taste of rice, therefore much amount of fertilizer was input to increase the rice biomass. In addition, farmer can get manure in free from livestock sector by exchanging the rice straw [10]. In Inbanuma watershed, there are 7,370 ha paddy field so that about 265-ton nitrogen and 52-ton phosphorus were flow into the Inbanuma lake from all paddy fields. With auto irrigator case, nitrogen and phosphorus load reduction were expected as 20.9 $\mathrm{kgN} / \mathrm{ha}(58 \%$ of $36 \mathrm{kgN} / \mathrm{ha})$ and $3.0 \mathrm{kgP} / \mathrm{ha}(43 \%$ of $7 \mathrm{kgP} / \mathrm{ha})$.

Table 2: Annual averaged nitrogen and phosphorus balance in irrigation period during 2012-2014.

\begin{tabular}{|c|c|c|c|c|c|c|c|c|c|}
\hline & & \multicolumn{4}{|c|}{ Nitogen } & \multicolumn{4}{|c|}{ Phosphorus } \\
\hline & & \multicolumn{2}{|c|}{ Conventional } & \multicolumn{2}{|c|}{ with Auto Irrigator } & \multicolumn{2}{|c|}{ Conventional } & \multicolumn{2}{|c|}{ with Auto Irrigator } \\
\hline & & (kg/ha) & (\%) & (kg/ha) & (\%) & (kg/ha) & (\%) & (kg/ha) & $(\%)$ \\
\hline \multirow{4}{*}{ INPUT } & rainfall & 7 & 4 & 7 & 4 & 0 & 0 & 0 & 0 \\
\hline & irrigation & 39 & 20 & 15 & 9 & 8 & 12 & 3 & 5 \\
\hline & fertilizer & 154 & 77 & 154 & 88 & 58 & 88 & 58 & 95 \\
\hline & Total & 200 & 100 & 176 & 100 & 66 & 100 & 61 & 100 \\
\hline \multirow{5}{*}{ OUTPUT } & $\begin{array}{c}\text { surface } \\
\text { runoff }\end{array}$ & 26 & 13 & 0 & 0 & 4 & 6 & 0 & 0 \\
\hline & percolation & 10 & 5 & 12 & 7 & 3 & 5 & 3 & 5 \\
\hline & harvest & 101 & 51 & 101 & 57 & 19 & 29 & 19 & 31 \\
\hline & $\begin{array}{l}\text { removal, } \\
\text { absorbed }\end{array}$ & 63 & 32 & 63 & 36 & 40 & 61 & 39 & 64 \\
\hline & Total & 200 & 100 & 176 & 100 & 66 & 100 & 61 & 100 \\
\hline
\end{tabular}

In Kashima irrigation district, there are 46.1 ha paddy field so that $968 \mathrm{~kg}$ nitrogen can be reduced. This amount of nitrogen was equal to nitrogen in waste water from 469 people. For the construction of waste water treatment plant (WWPT) in rural area, following equation is available for cost calculation.

$$
Y=11,186 . X 0.414+8.74 . X+11,027 \text { eq. (1) }
$$

where Y: plant construction cost (in unit of 1000 Japanese YEN), X: number of treatment people.

In case of the treatment plant for 496 peoples, construction cost is estimated about 160 million YEN ( $\fallingdotseq 1.9$ million USD). On the other hand, a cost of auto irrigator is 60,000 YEN/unit $(\fallingdotseq 720$ USD/ unit). Standard size of paddy in Japan is 0.3 ha so that 154 units of auto irrigators are needed to install the all paddies in Kashima district. Therefore, total installation cost was 9.24 million YEN $(\fallingdotseq 110,880$ USD). This cost was quite cheaper than that of WWTP.

\section{Conclusion}

In this study, field monitoring was conducted to grasp the current condition of water and nutrients balance in the paddy field. Large amount of irrigation water and nutrient fertilizer were inputted in monitoring paddy of Kashima district, because feed rice was cultivated in this paddy. And high input of water and nutrients leads much effluent load to downstream water environment. Recently, feed rice paddy area is increasing under the governmental regulation policy. Therefore, water pollution in closed type lake may become worse if feed rice paddy spread widely. Auto irrigation system is effective to save irrigation water input and pumping energy consumption and to conserve the water environment without more farmer's labor input for water management. 


\section{References}

1. Cantrell RP (2004) Challenges and opportunities for rice-based farming in the International Year of Rice and beyond. Paddy and Water Environment 2(1): 1-4.

2. JSIDRE (1999) Advanced paddy field engineering. Shinzan-sha Sci \&Tech, Tokyo, Japan, p. 39-50.

3. Tanji H, H Kiri, T Nakaya (2014) Functions and cost of irrigation service at the aichi irrigation sheme. Serviceology for Services 1: 365-37.

4. Clemmens AJ, RG Allen, CM Burt (2008) Technical Concepts Related to Conservation of Irrigation and Rainwater in Agricultural Systems. Water Resources Research 44(7): 1-16.

5. Sadler EJ, RG Evans, KC Stone, CR Camp (2005) Opportunities for Conservation with Precision Irrigation. Journal of Soil and Water Conservation 60(6): 371-379.
6. Amano K, S Nakanishi (2008) Water quality change in eutrophic lakes due to diversion and water supply from nearby rivers, case for Inba marsh. Proceedings of hydraulic engineering 52: 1267-1272.

7. Kitagawa M, Y Nihei, W Harada (2013) Study on nitrogen load of ground water into a influent river of lake Inba-numa. Journal of Japan Society of Civil Engineers, Ser. B1 (Hydraulic Engineering) 69(4): 1711-1716.

8. Hanson BR, JE Ayars (2002) Strategies for reducing subsurface drainage in irrigated agriculture through improved irrigation. Irrigation and Drainage Systems 16(4): 261-277.

9. Haruta S, Sudo M, Eguchi S, Okubo T, Kuroda H, et al. (2015): Effluent N, P and COD Loads from Paddy Fields in Japan: A Critical Review (in Japanease). Journal of Japan Society on Water Environment 38(4): 8191.

10. Rice RC, DJ Hunsaker, FJ Adamsen, AJ Clemmens (2001) Irrigation and nitrate movement evaluation in conventional and alternate furrow irrigated cotton. Trans ASAE 44(3): 555-568.

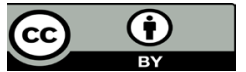

This work is licensed under Creative Commons Attribution 4.0 License

To Submit Your Article Click Here: Submit Article

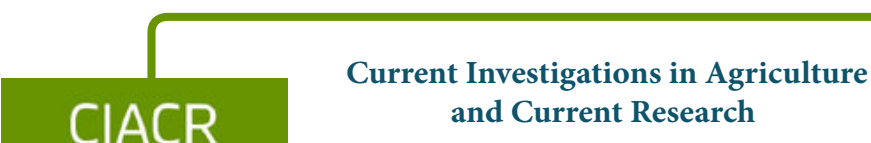

Assets of Publishing with us

- Global archiving of articles

- Immediate, unrestricted online access

- Rigorous Peer Review Process

- Authors Retain Copyrights

- Unique DOI for all articles 